\title{
The Policy of Large-Scale Social Restriction (LSSR): Prevention Effort of COVID-19 and Community Compliance in Indonesia
}

\author{
Dewi Kurniawati $^{1}$, Thinni Nurul Rochmah ${ }^{2}$, Agung Dwi Laksono ${ }^{3}$ \\ ${ }^{I}$ Master Program in Health Policy and Administration, Faculty of Public Health, Universitas Airlangga, Surabaya, \\ Indonesia, ${ }^{2}$ Researcher, Department of Health Policy and Administration, Faculty of Public Health, Universitas \\ Airlangga, Surabaya, Indonesia, ${ }^{3}$ Researcher, National Institute of Health Research and Development, The
} Indonesian Ministry of Health, Jakarta, Indonesia

\begin{abstract}
Covid-19 prevention efforts in Indonesia are carried out through several policies taken by the Government. One of them is the policy of conducting Large-Scale Social Restriction (LSSR) for regions that meet the requirements. LSSR and other policies that require community participation and discipline. The case curve is still high. Many violations still occur. The easing discourse has been LSSR rolled out. The study was aimed at evaluating the picture of the impact of LSSR policies in efforts to prevent the spread of Covid-19 in Indonesia concerning current public discipline. The study was conducted with a descriptive approach that was carried out through a literature study. The type of data used was secondary data. The results found that the policies issued in the Covid-19 prevention efforts, both in the form of policies on physical distancing, the use of masks, washing hands, to LSSR, all were related and depended on the level of community discipline to carry out and obey them. But the reality in the field of discipline that occurs both personally and collectively was still at a low level and requires further support. So that this also has an impact on the increasing occurrence of Covid-19 cases in various regions, even though the area has implemented an LSSR policy. It could be concluded that community discipline was the key to success in preventing Covid-19. The LSSR policy can also be successful if the community was able to discipline it obediently.
\end{abstract}

Keywords: Large-Scale Social Restriction, Health Policy, Community Compliance, Preventive.

\section{Introduction}

Covid-19 is a new type of virus so that not many people know and understand how to handle it. In the current condition Covid-19 is not a virus that can be ignored. This group of viruses can cause disease in birds and mammals, including humans. In humans, Covid-19 causes infections of the respiratory tract. If seen from the

\section{Corresponding Author:}

\section{Agung Dwi Laksono}

Researcher, National Institute of Health Research and Development, The Indonesian Ministry of Health, Jakarta, Indonesia

e-mail: agung.dwi.laksono-2016@fkm.unair.ac.id symptoms, people will think only limited to the common symptoms of influenza, but according to analysis in the world of medicine this virus is quite dangerous and deadly ${ }^{1}$.

At present, in 2020, the development of transmission of this virus is quite significant, its spread is worldwide and even all countries have felt its effects including Indonesia. The transmission of this massive virus makes the whole world uneasy. Even the WHO since January 2020 has declared the world into a global emergency related to this virus ${ }^{2}$.

As the outbreak of the Covid-19 virus became more prevalent, the Government of Indonesia issued several types of policies to anticipate and reduce the number of sufferers. Among them is determining the status of 
disaster emergency starting from 29 February 2020 to 29 May 2020 with a total time of 91 days. Besides, several health protocols have also been disseminated to be followed and implemented properly ${ }^{3}$.

The steps in the health protocol that were delivered did indeed require the participation of the discipline of the community, including the application of physical distancing, the use of masks and always doing proper handwashing. This concept aims to break the chain of transmission. But apparently in the field, this concept is often not obeyed, so there are still many violations of this health protocol. As there are still many people who are clustered in physical activity both in markets, shopping centers, and in other public areas. Doing activities without using a mask, and not doing hand washing before and after doing activities ${ }^{4}$.

The behavior of the community in responding to Covid-19 caused the spread of this virus to become more widespread and difficult to deal with, thus making the Legislative Body urge the Government to immediately form a National Team to deal with the centralized Coronavirus outbreak ${ }^{5}$. So that new policies emerged to limit movement society, namely the Large-Scale Social Restriction (LSSR) policy, another version of the lockdown policy carried out by other countries in the world, which is adjusted to the conditions of the people in Indonesia.New policies and commitments for implementation are needed to produce positive results ${ }^{6}$.

The implementation of the LSSR policy is based on Government Regulation Number 21 of 2020, which is an embodiment of Law Number 6 of 2018 concerning health quarantine. Some regions have received approval from the Ministry of Health to implement the policy. However, after it has been carried out in several places and sometimes, then an evaluation is conducted, there is a discourse to relax the LSSR policy. On the other hand, according to the University of Indonesia epidemiologist, Syahrizal Syarif, this easing should not have been carried out ${ }^{5}$.

Based on the background, several questions arise that are the focus of the research, namely how to address public discipline related to the Covid-19 preventive health protocol in Indonesia? And how are the positive and negative impacts if LSSR eased on the efforts to prevent the spread of Covid-19 in Indonesia related to the current level of public discipline?

\section{Material and Method}

The method used in this research was the study of literature, which was the study of the object of research in the form of literary works, whether in the form of scientific journals, books, articles in the mass media, or statistical data. The literature would be used to examine research problems and how to deal with them ${ }^{7,8}$. The nature of the study conducted was descriptive analysis which was to give a picture to the reader so that it could be a medium of public education ${ }^{9}$. The type of data used was secondary data.

\section{Findings:}

The Covid-19 Case in Indonesia: Today the Government of Indonesia continues to make efforts to minimize people infected with Covid-19. Initially the government did not want to provide information related to the coronavirus that entered Indonesia. This was done to avoid public panic and also avoid issues that are not clear.

Regarding the development of Covid-19, the Government made several policies. The first policy, in the form of Physical Distancing health protocol. This is intended to prevent transmission from patient to nonpatient through droplets or small splashes of mucus from the walls of the respiratory tract of someone who is sick when sneezing and coughing. For this reason, it is strongly recommended that you set the distance and do not conduct meetings or activities that gather large numbers of people so that there is a build-up or opportunities for people to intersect or be nearby can be avoided. Then the next policy is a health protocol that requires all people to carry out healthy and clean behavior by always washing their hands using soap or hand sanitizer both before and after carrying out activities related to others. Then the next policy related to the use of masks, both in the middle of a sick or healthy condition, which aims to reduce up to $70 \%$ of transmission through droplets.

Besides, there is also a policy regarding the Covid-19 virus inspection, which is hoped to be carried out on a massive scale and to cover the entire Indonesian population. Several kinds of inspection method are evaluated from its sensitivity, namely by using molecular method using PCR or immunoglobulin examination method as an initial screening test and can be carried out en masse. The purpose of this policy is to quickly find out the condition of the people exposed 
to Covid-19 so that further isolation can be carried out, both independently and in health care facilities.

To date, the number of people who have confirmed positive for Covid-19 is increasing and the number of deaths is still being found. To avoid confusing news, the government is also preparing reports that can be accessed online by the public through the official website ${ }^{1}$.

Large-Scale Social Restriction (LSSR) as an alternative policy in Indonesia: To prevent the spread of Covid-19 in Indonesia, the government finally decided to implement the Large-Scale Social Restriction (LSSR) on March 31, 2020. LSSR or which could be interpreted as partial lockdown or quarantine was one of the alternative interventions carried out by the Indonesian government after previously issuing policies related to health protocols that must be obeyed by the Indonesian people. This LSSR policy limits community mobility, one of which is by closing public areas such as schools and offices, to cut the spread of the SARS CoV-2 virus, the cause of Covid- $19^{10}$.

This LSSR policy is given by the Central Government (in this case the Ministry of Health's approval) to the Regions whose applications are deemed to meet the requirements. The legal basis for implementing this LSSR is Government Regulation number 21 of 2020 which is the manifestation of Law number 6 of 2018 concerning health quarantine.
The Discipline of the Indonesian Society: During the Covid-19 pandemic, as now, every citizen is expected to survive and adjust to life patterns. Collective discipline and behavior guided by health protocols are needed when they are active, especially in the public sphere.

According to the Government Spokesperson for Handling Covid-19, Covid-19 can only be prevented by strong discipline and cooperation spirit carried out by all elements of society as a whole without interruption. This discipline is related to compliance with government recommendations and policies to reduce the risk of the spread of Covid-19 becoming more widespread ${ }^{4}$.

According to the Big Indonesian Dictionary, discipline means the exercise of mind or character with the intention that all actions always obey the order, disciplined means to obey the provisions or rules according to applicable regulations. Discipline can not arise directly, it needs learning and gradual habituation until everything will be implemented spontaneously and become part of the soul. The application of discipline in society is important and needs to be fostered and enforced. Because discipline is the success capital of every activity. By upholding discipline in the community is one of the efforts to prepare people (the community), concerned so that they can develop their potential. With the theoretical discipline will be able to provide stimulation and encouragement so that they can become productive people ${ }^{11}$.

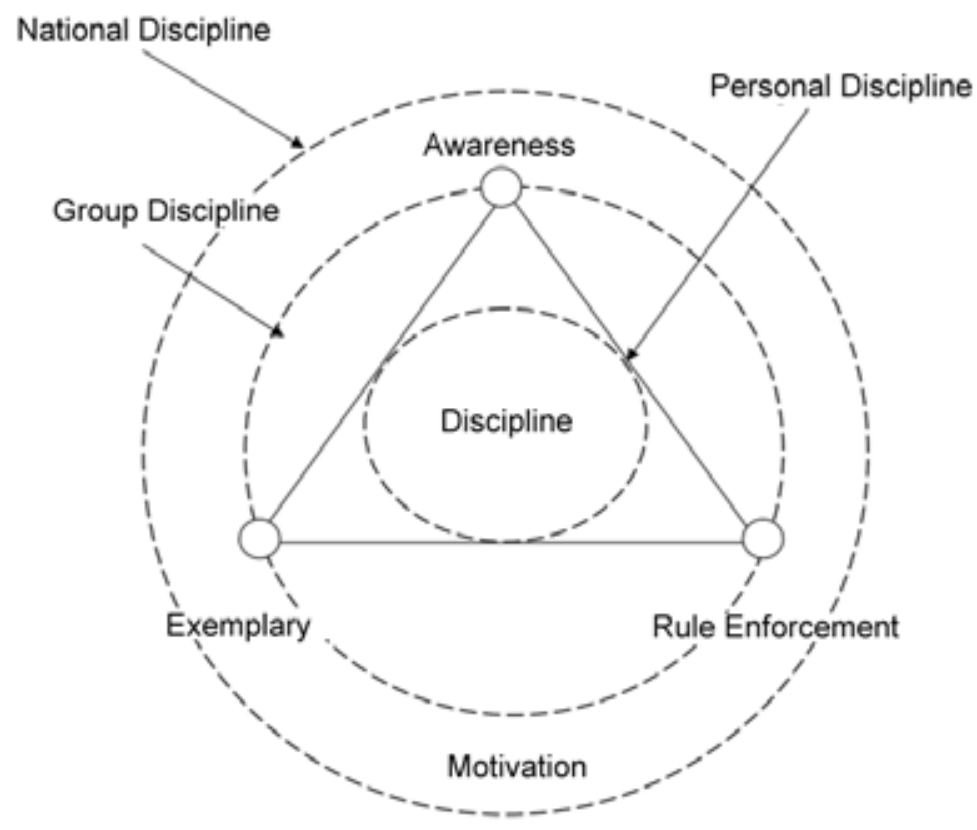

Figure 1. Discipline Level 
From Figure 1 it can be seen that forming a disciplined attitude in society is not easy. There is a need for learning or familiarity for every member of the community to be able to apply it. This attitude can be applied to start from someone since he was a child, namely through educators provided by parents or starting from the smallest environment, the family because the family environment has a central role in shaping the attitudes and behaviors of a person and the rest they will be formed or influenced by the environment that is around them namely the social environment of the wider community. The attitude of self-discipline based on awareness and because of a sense of caring and responsibility can certainly work well because it is not based on coercion from others. Discipline in each individual is what will form a collective discipline in the middle of society ${ }^{12}$.People often have their own views, which are sometimes different from the perception of health workers ${ }^{1314}$.

Impact of LSSR Policy and Community Discipline Level: In several countries in the world, many lockdown policies have been revoked. Activities related to the public interest began to be held again. The economy was revived after a long dormant period.

The Indonesian government, who learned this, also felt that limiting the movement of the people would no longer be an effective policy, because this policy had an impact on many things. Even in several discussion sessions, the team leader of the National Covid-19 taskforce handling team stated that socially we will experience something new normal or have to adapt when we are active and working. Besides, the community is also required to avoid physical contact with others or avoid the crowd at work, as well as comply with existing protocols, such as health protocols. Still, according to him, this transformation is to organize life and new behavior, when the pandemic, which will then be carried forward in the future until the discovery of this vaccine for Covid-1915.

However, this is less agreed by epidemiologists, according to the analysis of the epidemiologist curve in Indonesia it does not meet the standards, so it is difficult to do an assessment. Case curves that continue to show an increase should also be taken into consideration. If there is a discourse about the LSSR policy easing, some conditions must have been fulfilled, such as related to the number of cases, the shape of the epidemiologist curve, and the minimum number of examinations that must be performed on the Indonesian population ${ }^{5}$.
Public discipline is also an important benchmark before the easing of the LSSR policy is rolled out. Disciplined society will be the main key to preventing the spread of Covid-19. The reality in the field, at some point, the accumulation of people is still often found, even becoming the national news headline, even though it is happening in areas that are being applied LSSR policy. Besides, according to the results of several social studies, people show that they act according to their desires and do not heed health protocols that the government calls for, such as not wearing masks, not washing hands, and still carrying out social activities that involve many people ${ }^{16}$.

If this condition is not immediately corrected, this will be a time bomb against efforts to prevent the spread of Covid-19 which is touted by the government. Not wearing a mask as protection will cause droplets to spread easily from one person to another, which means that it will cause the affected person to become a carrier of the virus or even become a new sufferer. Not doing handwashing properly will also be a medium for massive viral growth. In addition to the absence of movement restrictions, the spread of viruses that have been carried by these undisciplined hosts can become more widespread across distances and boundaries. As a result it is not impossible to see a significant increase in the number of cases, especially in several key areas.

For this reason, if Covid-19's prevention efforts are to be successful, the government should re-evaluate these conditions in the community, if necessary the community must do intensive coaching in advance, be prepared until it is fully ripe to apply the health protocol in a disciplined manner until collective discipline formed throughout all elements of society. Only after that, the discourse about the LSSR policy can be evaluated for its existence and success.

\section{Conclusions}

The essence of this paper is that discipline was the key to success in preventing the spread of Covid-19 in Indonesia. Personal discipline would shape the collective discipline, which would have a wide impact on society. This discipline also could not be done by only one component but requires cooperation and the willingness of all parties to participate.

The ongoing LSSR in several regions also has not shown significant results. Repeated evaluations still need to be made regarding their effectiveness. Community 
participation in the implementation of LSSR was very necessary. LSSR which was implemented without any discipline from the community will take place without meaning.

Acknowledgments: The author would like to thank Universitas Airlangga, which has allowed completing this final project.

Source of Funding: Self-funding

\section{Conflict of Interests: Nil}

Ethical Clearance: This study utilizes secondary data that has been published. So in conducting the study there is no need for ethical clearance.

\section{References}

1. Covid-V, Yunus NR, Rezki A. Kebijakan Pemberlakuan Lock Down Sebagai Antisipasi Penyebaran Corona Kebijakan Pemberlakuan Lockdown Sebagai Antisipasi Penyebaran Corona Virus Covid-19 $\square$. SALAMJurnal Sos dan Budaya Syar'i. 2020;7(April):227-38.

2. Telaumbanua D. Urgensi Pembentukan Aturan Terkait Pencegahan Covid-19 di Indonesia. Qalamuna J Pendidikan, Sos dan Agama. 2020;12(1):59-70.

3. Dana Riksa Buana. Analisis Perilaku Masyarakat Indonesia dalam menghadapi Pandemi Virus Corona (Covid 19) dan Kiat Menjaga Kesejahteraan Jiwa. SALAMJurnal Sos dan Budaya Syar'i. 2020;7(Nomor 3):217-26.

4. Agus Wibowo. Kementerian Komunikasi dan Informatika. 2020.

5. CNNIndonesia. Pelonggaran PSBB, Antara Kurva Corona dan Beban Berat Ekonomi. 2020.

6. Wulandari RD, Supriyanto S, Bagus Qomaruddin M, Damayanti NA, Laksono AD. Change commitment and change efficacy of public health center in indonesia in implementing efforts to improve the quality of health services. Indian $\mathrm{J}$ Public Heal Res Dev. 2019;10(10):1923-8.
7. Hamal M, Dieleman M, De Brouwere V, Buning TC. How do accountability problems lead to maternal health inequities? A review of qualitative literature from Indian public sector. Public Health Rev. 2018;39(1):Article number 9.

8. Wu R, Li N, Ercia A. The effects of private health insurance on universal health coverage objectives in china: A systematic literature review. Int $\mathrm{J}$ Environ Res Public Health. 2020;17(6):Article number 2049.

9. Kusumawardani N, Soerachman R, Laksono AD, Indrawati L, Hidayangsih PS, Paramita A. Qualitative Method for Health Research (Penelitian Kualitatif di Bidang Kesehatan). Yogyakarta: PT Kanisius; 2015.

10. Febi Dwirahmadi. Tiga salah kaprah penerapan PSBB di Indonesia dan solusinya. The Conversation. 2020 .

11. Avin Fadilla Helmi. Disiplin Kerja. Bul Psikol. 1996;Tahun IV,:32-41.

12. Masitoh D. Tingkat Kedisiplinan Masyarakat Dalam Menjaga Budaya Hidup Bersih Terhadap Lingkungannya. Universitas Negeri Semarang; 2006.

13. Megatsari H, Laksono AD, Ridlo IA, Yoto M, Azizah AN. Community Perspective about Health Services Access. Bull Heal Syst Res. 2018;21:247253.

14. Ipa M, Widawati M, Laksono AD, Kusrini I, Dhewantara PW. Variation of preventive practices and its association with malaria infection in eastern Indonesia: Findings from community-based survey. PLoS One. 2020;15(5):e0232909.

15. Dhita Setiawan. Di Masa Pandemi Covid-19, Disiplin Kolektif dalam Beraktivitas Tantangan Besar Semua Pihak - Pikiran-Rakyat. 2020.

16. Emir Chairullah. Wapres_Kedisiplinan Masyarakat Saat PSBB Masih Jauh dari Harapan. www. mediaindonesia.com. 2020. 